\title{
The Middle East perspective of Corporate Social Responsibility
}

\author{
Y. AL-DAAJA1, GY. N. SZABADOS² \\ 1Debreceni Egyetem, Gazdaságtudományi Kar, Szervezés és Kommunikáció Tanszék, albwairy@yahoo.com \\ ${ }^{2}$ Debreceni Egyetem, Gazdaságtudományi Kar, Szervezés és Kommunikáció Tanszék, \\ szabados.gyorgy@econ.unideb.hu
}

Abstract. Corporate social responsibility (CSR) in the Middle East is gaining more importance than in the past. Although it still remains more about philanthropy and charity, it moves towards a more strategic approach which includes formalizing ways of giving, as a set of non-random actions, and focuses more on addressing social ills and environment, economic challenges, that are hindering development. However, the business in the region has not yet taken the step to fully integrate the CSR into their core business operations. The most common challenges that facing the CSR implementation are the lack of government requirements and incentives, spreading awareness, building CSR partnership model, going beyond the marketing and PR campaigns, and full integration of CSR into the business strategy. In this paper, we aim to introduce the current state of the CSR in the Middle East and its perspectives, besides reviewing its evaluation stages, motivations, and current challenges. Moreover, we aim to examine CSR common practices through examples from the financial sector. The research method applied in this research is based on secondary data sources and we have used desk research to illustrate most important points and findings on the topic.

THE PUBLICATION IS SUPPORTED BY THE EFOP-3.6.2-16-2017-00003 PROJECT. THE PROJECT IS CO-FINANCED BY THE EUROPEAN UNION UNDER THE EUROPEAN SOCIAL FUND

\section{Introduction}

During the past few decades and, under the influence of globalization and economic liberalization, significant changes in state and market relations have been observed in the Middle East.

In response, the governments of the region began to promote private sector participation in the development process, realizing that the national economic, social, environmental problems are too complex that they cannot be solved by one sector. Indeed, the development process needs a meaningful participation of business organizations in the socio-economic issues, it requires from all parties in the society to play an expanded role in the national development. Thus, the Corporate Social Responsibility [CSR] concept seems to be the suitable tool for building useful partnership relation that meets the social challenges while advancing economic growth and prosperity. Corporate social responsibility is one of the most widely functional mechanisms for fostering the partnership between government and business [1]. Also," the UN's Division for Sustainable Development in its study, "CSR 
and Developing Countries has argued that governments across the world need to promote CSR to improve national competitiveness and to help deliver state-policy goals [2].

While, the concept of CSR as widely spread in the West, it is not a strange concept in the Middle East. Instead, it is a natural outlook of the region's cultural heritage and religious belief, examples of good CSR practices can be found in many countries of the region; Tunisia, Jordan Egypt, Lebanon, the Gulf States, Morocco, Turkey, Syria, etc. [3]. However, there is a significant difference between countries in practice and applying CSR. For example, companies operate in UAE and Oman show a serious commitment to establishing CSR practices while in Lebanon, public relations activities masked as CSR [4] [5] also in Tunisia, it does not have a developed structure for defining companies compliant with corporate social responsibility [6], and in such countries like Syria and United Arab Emirates (before the Arab uprisings) the terms of promotion and reception of the CSR shows a similarity in features. Despite that in Syria the CSR adopted by state-owned enterprises and crony capitalists in United Arab Emirates, the CSR activities still hold a different meaning in Middle East countries, they share similar features in terms of promotion and reception of CSR [7].

The Middle East is a "geographical and cultural region located primarily in western Asia, but also in parts of northern Africa and southeastern Europe" [8], it holds a unique religious culture as well as norms and values, and while some of their economies depend on natural resources, some still suffered from political and macro-economic instability. Consequently, there is a significant difference among Middle East nations in applying and practicing CSR. Some countries and companies in the region are further ahead than others. A World Bank report finds out, that CSR has different meanings from country to country in the MENA region [9].

While the CSR in the Middle East is gaining more importance than in the past and became more feasible, this paper aims to introduce the Middle East perspectives it and how business organizations in the region understand CSR and its dimensions. Moreover, we aim to examine CSR common practices with examples from the financial sector, besides reviewing its evaluation stages, motivations, and Future Challenges.

\section{Methodology}

This paper is conceptual in nature. Desk research has been conducted to illustrate the most important points of this paper, the sources of data were secondary in nature and collected most particularly from journal articles, subject related websites, various newspaper articles, magazines, and internet etc. "Secondary analysis is a form of research in which the data collected and processed by one researcher are reanalysed-often for a different purpose-by another based on an extensive literature review on CSR [11] 


\section{CSR in the Middle East}

\subsection{The Traditional approach.}

Historically, the practices of CSR in the middle east are implemented in the context of philanthropic, charitable, voluntary actions, based on cultural heritage and Islamic traditions, and initiated by both individuals and businesses. "CSR in the Middle East has distinctive roots and unique expressions that do not always mirror the current understanding and practice in the West"[12]. Moreover, "philanthropy is the most common manifestation of corporations' social agenda in the MENA countries, based on the Middle East cultures and Islamic traditions" [9].

Under the category of philanthropy, there are practices for giving, attached to Islamic traditions which help explain the current focus on corporate philanthropy, "the practices of giving like Zakat (mandatory giving in Islam), Takaful Insane (humanity solidarity) and Waqif (Islamic endowment), are strongly rooted in the region cultural and religious traditions", [12]. However, "it is still difficult to find any difference between the practices of giving like Zakat and CSR in practice and this complicates the entrance of CSR to the Middle East" [7].

In the Middle East, the stakeholder's expectations of business are varying between countries, [9], and traditionally the general perception of CSR in the region is that "social responsibility is the primary role of the state" [13]. Furthermore, there is a disagreement on the term itself. Some business leaders dislike the label CSR [14]. The CSR traditional practices in the region are overlapping, sporadic and unorganized with lack of proper impact assessment and monitoring and the three main themes that described the CSR traditional practices in the region are: It's a public relation and a marketing tool, there is an absence of the CSR partnership model, and CSR still without a vision or strategic approach [15].

\subsection{Changing the Agenda}

While the indications of some researches show that CSR in the Middle East emphasis primarily on charitable and philanthropic activities, the business organization in the region has changed their CSR agenda. It appears to have a broader understanding of CSR that goes beyond charitable and philanthropic practices, it starts putting together a real plan to produce products or provide services that are in the best interests of society. Indeed, it's clear that it is getting more strategic in nature and more diversified. Nowadays, there is a common passion and a strong support for CSR practices, therefore, the question that arises in the Middle East is not whether the corporation should do better for the community, but how?

In recent years corporations in oil- rich countries like the United Arab Emirates, Saudi Arabia, And Qatar etc., has also brought CSR into their business strategy adopting more sustainable Practices in the business [16]. A recent study conducted by Bayt.com under the headline of "How CSR is making an impact in the Middle East and North Africa" shows that 90\% percent of participants feel that the corporate sector in the Middle East needs to possess a moral responsibility towards CSR. $80 \%$ of 
professional participants in the Middle East feel that CSR efforts are making a positive impact in the region. $95 \%$ of the sample feel it's mandatory that their company is socially responsible. From the perspectives of the professionals of the Middle East, the main benefit of adopting CSR activities are the elevated corporate reputation and the other benefits from their point of view are the improved relationship with the stakeholders as well as with the community. Besides it, most of them (94.3\%) gave the opinion that there is a direct relationship between effective CSR and business success. According to these opinions, there is no chance to ignore the CSR activities or to take it lightly as before [17].

At the beginning of the 21st century, the role of governments has been expanded, in fact, there has been increasing emphasis on environmental issues, through effective policies and strategies, which encouraged by the international community and the media also exploded literally the importance of the CSR concept and formed professional CSR networks. For example, the CSR Middle East network, which has 1,285 members from 18 countries, and also steps have been taking to spread the awareness and formalize the idea of CSR through national and regional CSR-related conferences [18]. Furthermore, the family business starts being part of the society and lunched some of CSR initiatives, Abdul latif Jameel Community Initiatives International [ALJCI] invests in 2013 some $(\$ 29 \mathrm{~m}-\$ 40 \mathrm{~m})$ a year into job creation initiatives and a further $(\$ 75 \mathrm{~m}-\$ 83 \mathrm{~m})$ in loans and microfinance for entrepreneurs [5]. However, the region still needs to raise the importance of CSR as a need and as a recognized potential within private sector decision makers and corporate consultants.

\subsection{Evolution of CSR in the Middle East}

To characterize and understand the evolution of the corporate social responsibility concept and its changes over time in the Middle East, we divided the transformation process into two phases based on political - economic background.

\begin{tabular}{|l|l|l|}
\hline \multicolumn{1}{|c|}{ PHASE } & CSR APPROACH & \multicolumn{1}{c|}{ KEY STRATEGY } \\
\hline $\begin{array}{l}\text { Phase I } \\
\text { TIL.2000 }\end{array}$ & $\begin{array}{l}\text { Charity and } \\
\text { philanthropy } \\
\text { Approach }\end{array}$ & $\begin{array}{l}\text { A non-Institutionalized phenomenon, random actions labeled as CSR } \\
\text { practices, based on cultural and Islamic traditions }\end{array}$ \\
\hline $\begin{array}{l}\text { Phase II } \\
\begin{array}{l}\text { 2000- } \\
\text { present }\end{array}\end{array}$ & $\begin{array}{l}\text { Semi-Strategic } \\
\text { Approach } \\
\text { (Smart } \\
\text { philanthropy) }\end{array}$ & $\begin{array}{l}\text { Formalize ways of giving through planned, non-random actions and } \\
\text { focus more on addressing social ills and economic challenges that } \\
\text { are hindering development, like unemployment, poverty , health and } \\
\text { education }\end{array}$ \\
\multicolumn{3}{|c}{ Table 1. Phases of CSR practices in the M.E. } \\
Source: Authors survey of literature on CSR (2017)
\end{tabular}

\subsubsection{Phase One: Charity and philanthropy Approach}

Till the beginning of the 2000s, the CSR practiced in the middle east as a charitable, and philanthropic work and the philanthropy may be identified in terms of sporadic, incidental and un-planned actions, which required a little of administrative efforts. It is an activity that performed, but not deliberated and dedicated to serving the community, where the duty of giving back is rooted in the region's culture and religion believes. Usually, initiate to satisfy the interests of a broader group of stakeholders and implemented by non- governmental organizations or cultural and sports institution, according to 
a Coutts philanthropy report Company in the GCC (gulf cooperation council) donated $\$ 727$ million to charity in 2012, accounting for 18 per cent of regional donations [5].

\subsubsection{Phase Two: Semi -Strategic Approach (Smart philanthropy)}

While CSR still remains within the philanthropic space, a shift in the corporate social responsibility practices has been witnessed in the early 2000s, towards creating shared value through stargazing the ways of giving as planned, non-random actions as well as the firms start to focus more on addressing social ills and economic challenges that are facing the development, like unemployment, poverty, health and education and. Mostly due to The Arab Spring, which refers to "the democratic uprisings that arose independently and spread across the Arab world in 2011" [19] .The CSR concept has become a political issue and a way of social connection, and the state realizes the importance of the collaboration of all parties in the society to provide necessary help to the poor as well as solve their problem and raise their standard of living. The business organization is broadening the meaning of CSR to encompass, programs like increasing skills development programs or supporting small- and medium-sized enterprises [SMEs], providing greater assistance and supporting job creation. Furthermore, the family business in this stage also bears its share and start being part of the society and launched some of CSR initiatives, for example on this issue is the Abdul Latif Jameel Community Initiatives International itself, as part of the family-run Saudi conglomerate. "ALJCI claims to have created more than 465,000 job opportunities in Saudi Arabia, Morocco, Egypt, and Turkey. Its schemes include helping women from low-income families start home businesses and granting interest-free loans for young people to launch small projects "[5].

\section{CSR Challenges in the Middle East}

We refer here to some of the challenges that are facing the implementing of CSR activities to achieve long-term, sustainable goals. Some challenges are "embedded in the entitlement mentality, which has hardened over the years; others are structural in nature" [13]. These all must be taken into account when discussing the future plans for the CSR in the region.

- Not a core business strategy: business in the region need to face the challenges and move forward to integrate CSR into their vision and philosophy as a fully integrated core business strategy also they need to engage less in philanthropy and charity practices and invest more in development and sustainability.

- CSR as a PR and Marketing Tool: while in most cases CSR in the region is purely marketing with the aim to increase the companies' reputation and turnover. A business in the region needs to take CSR very seriously and take a lot of initiatives for a sustainable CSR development, and look beyond the marketing goals.

- Building a CSR Partnership Model: CSR is a collective responsibility, which required a holistic approach through a dialogue between all parties in the society toward accepting the CSR and' it has been observed that the lack of the proper CSR partnership model leaves CSR practice to personal connections and professional networks' [15].

- Lack of government requirements and incentives: as a key player and one of the main CSR stakeholder with substantial power and authority, the government itself, must take the lead in building CSR guidelines and promoting ethical responsibility, since it needs to endorse legislation 
and formalize CSR activities through necessary laws that motive the private sector to contribute to economic and social developments.

- Awareness challenges: most countries in the Middle East still in the early stages of awareness, and societies still don't understand the difference between ethical behavior and obeying the law in evaluating the business practices.

\section{CSR Driving Forces in the Middle East.}

The main forces that motivated the CSR practices of the business organizations in the Middle East are explained at the table below as endogenous and exogenous factors:

\begin{tabular}{|l|l|}
\hline \multicolumn{1}{|c|}{ ENDOGENOUS FORCES } & \multicolumn{1}{c|}{ EXOGENOUS FORCES } \\
\hline Arabic Spring & International standards \\
\hline Regularity Pressure & Technological revolution \\
\hline Market Pressure & Globalization \\
\hline MNCs in the Region & \\
\hline Economic liberalization & \\
\hline Culture and religion & \\
\hline
\end{tabular}

Table 2.c CSR driving forces in the M.E.

Source: Authors survey of literature on CSR (2017)

In the global context, literature revealed that the growing demand and pressure upon firms to practice the CSR concept is usually attributed to the rise of globalization, and, the technological revolution associated with the so-called internet-booming era'. In addition, the growing influence of the media and increased societal awareness of the impact of business on societies and finally the international standers and guidelines set by the united nation and other international organizations. For the Middle East, in particular, it's also accompanied by following internal factors, such as culture and religion. The multinational companies operating in the region (MNCs) and the new government rules and regulation, also, the Arabic spring, which "refers to the democratic uprisings that arose independently and spread across the Arab world in 2011“. Finally, the market competition and the need for the CSR as marketing and public relation tool.

\section{The Financial sector CSR practices: examples from the region with a specific focus on sport.}

The banking and financial sector in the region is very mature, it is one of the most active sectors in supporting CSR practices, and the middle east up until now has a dual banking system, whereby the Islamic banking system operates in parallel with the conventional system. There are some banks in the Middle East who are able to create some milestones and able to differentiate themselves from others regarding innovative CSR practices such as: 
- Qatar National Bank

Qatar National Bank [QNB] is a Qatar based commercial bank whose headquarter is in Doha, Qatar. It was established in 1964 and currently has subsidiaries and associates in 27 countries spanning 3 continents. In the year of 2014, it was the second largest bank in the region in terms of assets. Considering CSR, QNB is in a leading position, as it is committed to allocating a percentage of its annual profits to providing general support to specific six sectors as mentioned below

1. Arts and Culture 2. Youth and Education 3. Economic and International Affairs. 4. Health and Environment 5. Social and Humanitarian and 6. Sport.

In the banks sports agenda in particular the QNB has supported Qatar bid to host the FIFA World Cup in 2022 and declared its commitment to develop and implement plans to ensure the financial needs of organizers, also backed the Olympic Committee for Special Needs to help physically and mentally challenged individuals to reach their potential. Furthermore, the bank sponsors Qatar's four major sports championships - football, basketball, handball and volleyball, and integrated its support for sports by the formation of a football team and a cricket team that participated in various tournaments in Doha, and its considered as one of the major sponsors of the Qatar ExxonMobil Tennis Tournament for nearly two decades. The bank is also known as the "an enthusiastic supporter of the Qatar Motocross and Motorcycling Federation including a sponsor of Qatari Middle East Rally Champion In addition, it has supported the International Squash Championships and the Military Open Tennis Championship which is one of the few events in Qatar that brings together members of the armed services and civilians" [20].

- Bank of Jordan (B.O.J).

Bank of Jordan [B.0.J.] was established in Jordan in 1960. It is considered as one of the five major pioneering local banks with a capital of JD200 million. The bank has branches, offices, and ATMs in Jordan and Palestine, the bank CSR agenda includes various CSR activities in different fields like, education, cultural, sports, for instance, in the sports field the bank sponsors Amman Baccalaureate School Marathon for 2nd Year Students and their parents, competed in the eighthour race without interruption. In the education sector, the Bank provided ten scholarships at the Faculty of Educational Sciences and another 33 scholarships were funded in cooperation with the Ministry of Higher Education and Scientific Research. The bank also has sponsored a talented student at the prestigious King's Academy. The bank celebrated the "Open Days" initiative, with the Children's Museum, allowing thousands of children and their parents to enter for free on the first Friday of each month. In Palestine, the Bank is helping to improve children's creative reading and writing skills in partnership with local Foundation. The Bank also cooperated with the Central Bank of Jordan to enhance financial awareness among citizens [21].

- Al-Rajhi Bank.

Al-Rajhi Bank is a KSA based bank, and it is a major investor in Saudi Arabia's businesses. It is also one of the largest joint stock companies in Saudi Arabia. Its head office is located in Riyadh. The CSR activities practiced by Al Rajhi Bank are performed in different areas, including healthcare, education, and general social programs.

Al Rajhi Bank conducts different types of large-scale healthcare programs associated with the antismoking foundation as the part of their CSR activities. The Bank also signed an agreement with the Ministry of Social Affairs for a training and development programs for both men and women, and then create a job opportunity for them in the banking sector. They also have a collaboration with the Women's University to support women in the fields of the body, hair care, and other related fields. With these programs, they train women and provide necessary support to establish their own small business ventures [22]. 


\section{Conclusion}

The Middle East has its unique flavor with its economy, which depends on natural resources, and the majority of Middle East corporations are small and medium-sized firms. In addition, the region holds a unique religious culture as well as norms and values, based on Islamic traditions. Furthermore, some countries still suffer from political and macro-economic instability. Consequently, the World Bank report finds out, that CSR has different meanings from country to country in the Middle East countries [9].

While the CSR in the Middle East still remains within the philanthropic space, due to its deep cultural heritage and religious beliefs. The business organizations in the region move forward and gradually organizing its involvements in more structured CSR approach, it has been observed that different companies in the region start to focus more on adopting CSR in their strategies and figure out that they can do better on the field of CSR and use their internal resources to create abettor conditions for their societies. However, companies in the Middle East are still in the early phases of strategizing the CSR and have a long path to go for achieving sustainability when compared to the Western countries.

The CSR in the region, facing many challenges, it is not yet a core business strategy, and the business in the region still needs to move forward, for better integration of CSR into their core business strategy and their daily operations beyond the traditional practices, like a simple donation or planting trees. Moreover, CSR needs a holistic approach for successful implantation through a partnership between all the parties in the society while the government should take the lead in the whole process.

The banking and financial sector in the region is very mature, it is one of the most active sectors in supporting CSR practices, and in some countries, it takes the leading role in implementing CSR initiatives. In this paper we draw attention to some CSR activities of banks and the financial sector which targeted different social areas.

While CSR in the middle east witnessed its true movement recently, we can delineate two phases in the evolution of CSR in the region, first it was practiced as traditional act based on religious and culture factors then, at the beginning of the 2000s. Now it moves forward for more institutionalized forms of giving and becoming more strategic, it may be called a semi-strategic approach, which motivated by external and internal factors, where companies start to deal with the whole community and targeting the social issues in the society. Still, it has not yet taken the step to fully integrated the CSR into their core business operations, with a vision for achieving sustainability goals.

\section{References}

[1] D. Cetindamar (2007) Corporate social responsibility practices and environmentally Responsible Behavior: The case of the United Nations Global Compact. Journal of business Ethics, 76 (2) pp. 163-176.

[2] H. Ward - E. Wilson - L. Zarsky - T. Fox (2007) CSR and Developing Countries: What Scope for Government Action?" Innovation. Briefs, 1 pp. 1-7. 
[3] Al-urdun AL jaded research center, (2005) Strengthening Corporate Citizenship, Jordanian forum for Economic Development (JFED), 9TH issue, July 2005, Amman-Jordan

[4] L. Diab (2017) CSR Perspectives for the Middle East. Retrieved from https://www.ecomena.org/csr-middle-east

[5] A. Cernigoi (2013) CSR in the Middle East: good business, Philanthropy Age http://www.philanthropyage.org/finance/CSR in the Middle East: good business-in-middleeast-good- business accessed on 18/11/2017

[6] CSR Middle East, (2012) Tunisia: New Standards for Corporate Social Responsibility http://csrmiddleeast.org/profiles/blogs/tunisia-new-standards-for-corporate-socialresponsibilityR. Middle east.2012,)

[7] K. Selvik (2013) CSR in the Arab World: A mission impossible? Retrieved on 15th of Nov 2017from https://www.cmi.no/news/1142-csr-in-the-arab-world-a-mission-impossible

[8] www.worldatlas.com Retrieved on 15th of DEC.2017

[9] M. Ararat (2006) Corporate Social Responsibility across the Middle East and North Africa, Faculty of Management, Sabanci University, Draft available at SSRN: http://ssrn.com/abstract $=1015925$

[10] E. Babbie (2007) The Practice of Social Research. Thomson Wadsworth, Belmont.

[11] D. Jamali - Y. Sidani (Eds.). (2012) CSR in the Middle East: Fresh perspectives. Springer.

[12] D. Jamali - R. Mirshak (2006) Corporate Social Responsibility (CSR): Theory and Practice in a Developing Country. Journal of Business Ethics, 72 pp. 243-262. Springer 2006 DOI 10.1007/s10551-006-9168-4.

[13] A. J. Al-Ali (2012) Corporate social responsibility in Saudi Arabia. Middle East Policy, 19 (4) pp. 40-53.

[14] G. Salim - F. Adra - N. Hage-Chahine - D. Jamali (2013) The rise of corporate social responsibility, A tool for sustainable development in the Middle East, report published by Booz \& Company in 2013.

[15] R. Sara (2014) Corporate social responsibility in Egypt: study on the current practice, challenges and potentials. , a thesis submitted to the public policy and administration department in partial fulfillment of the requirements for the degree of master of public policy and administration, school of global affairs and public policy, the American university in Cairo

[16] H. M. Yawar (2009) CSR Pakistan Evolution, rise and impact of socio-economic development. Capital Business (Pvt) Ltd. Gulberg III, Lahore, Pakistan

[17] Bayt.com. (2013) Research Report- 18062. Bayt.com Infographic: How CSR is making an impact in the Middle East and North Africa? Retrieved on 17th of Nov 2017 from https://www.bayt.com/en/research-report-18062/

[18] D. Jamali (2014) Overview of corporate social responsibility in the Middle East. The World Financial Review, pp. 71-72.

[19] Source Watch (2017) https://www.sourcewatch.org/index.php/Arab_Spring

[20] QNB CSR and Staff Engagement Policies. (N.d.). Retrieved from https://www.qnb.com/cs/Satellite/QNBQatar/en_QA/AboutQNB/enCorporateSocialResponsi bility, retrieved on 17th of JAN. 2017

[21] Bank of Jordan, http://www.bankofjordan.com/page/about-boj-csr, retrieved on 17th of JAN. 2017 
International Journal of Engineering and Management Sciences (IJEMS) Vol. 3. (2018). No. 4

DOI: 10.21791/IJEMS.2018.4.24.

[22] Al Rajhi Bank, Corporate Social Responsibilities. (n.d). Retrieved on 17th of Nov 2017, from http://www.alrajhibank.com.sa/en/investor-relations/about-us/pages/corporate-socialresponsibility.aspx 